Article

\title{
Research on the Combustion, Energy and Emission Parameters of Various Concentration Blends of Hydrotreated Vegetable Oil Biofuel and Diesel Fuel in a Compression-Ignition Engine
}

\author{
Alfredas Rimkus ${ }^{1,2, *(\mathbb{0})}$, Justas Žaglinskis ${ }^{3}$, Saulius Stravinskas ${ }^{1}$, Paulius Rapalis ${ }^{4}$, \\ Jonas Matijošius ${ }^{5}$ iD ák Ákos Bereczky ${ }^{6}$ \\ 1 Department of Automobile Engineering, Faculty of Transport Engineering, \\ Vilnius Gediminas Technical University, J. Basanavičiaus Str. 28, LT-03224 Vilnius, Lithuania \\ 2 Department of Automobile Transport, Technical Faculty, Vilnius College of Technologies and Design, \\ Olandu Str. 16, LT-01100 Vilnius, Lithuania \\ 3 Laboratory of Waterborne Transport Technologies, Open Access Centre for Marine Research, \\ Klaipėda University, H. Manto Str. 84, LT-92294 Klaipėda, Lithuania \\ 4 Marine Chemistry Laboratory, Open Access Centre for Marine Research, Klaipeda University, \\ H. Manto Str. 84, LT-92294 Klaipeda, Lithuania \\ 5 Institute of Mechanical Science, Faculty of Mechanical Engineering, Vilnius Gediminas Technical University \\ Basanavičiaus str. 28, LT-03224 Vilnius, Lithuania \\ 6 Department of Energy Engineering, Faculty of Mechanical Engineering, Budapest University of Technology \\ and Economics, Bertalan Lajos Str. 4-6, Bldg. D. 208, H-1111 Budapest, Hungary \\ * Correspondence: alfredas.rimkus@vgtu.lt; Tel.: +370-615-711-61
}

Received: 12 July 2019; Accepted: 30 July 2019; Published: 1 August 2019

check for updates

\begin{abstract}
This article presents our research results on the physical-chemical and direct injection diesel engine performance parameters when fueled by pure diesel fuel and retail hydrotreated vegetable oil (HVO). This fuel is called NexBTL by NESTE, and this renewable fuel blends with a diesel fuel known as Pro Diesel. A wide range of pure diesel fuel and NexBTL100 blends have been tested and analyzed: pure diesel fuel, pure NexBTL, NexBTL10, NexBTL20, NexBTL30, NexBTL40, NexBTL50, NexBTL70 and NexBTL85. The energy, pollution and in-cylinder parameters were analyzed under medium engine speed ( $n=2000$ and $n=2500 \mathrm{rpm}$ ) and brake torque load regimes (30-120 Nm). AVL BOOST software was used to analyze the heat release characteristics. The analysis of brake specific fuel consumption showed controversial results due to the lower density of NexBTL. The mass fuel consumption decreased by up to $4 \%$, and the volumetric consumption increased by up to approximately $6 \%$. At the same time, the brake thermal efficiency mainly increased by approximately $0.5-1.4 \%$. $\mathrm{CO}, \mathrm{CO}_{2}, \mathrm{NO}_{\mathrm{x}}, \mathrm{HC}$ and $\mathrm{SM}$ were analyzed, and the change in $\mathrm{CO}$ was negligible when increasing NexBTL in the fuel blend. Higher SM reduction was achieved while increasing the percentage of NexBTL in the blends.
\end{abstract}

Keywords: Compression-Ignition (CI) engine; hydrotreated vegetable oil (HVO); NexBTL; engine efficiency; engine pollution

\section{Introduction}

Year after year, pollution and environmental protection become more relevant, as well as energy savings and independence. The transportation sector is one of the main polluters and energy consumers. Great attention is paid to pollution protection by engine producers because every few years the requirements become more strict [1-4]. Despite the development of alternative power drives and 
fuels, in the 21st century, common means of transportation still mainly rely on fossil fuels. Obviously, vehicles in different cases could be in operation for few decades, and outdated means of transportation with old pollution reduction technologies are still running today. It is clear that to take each outdated means of transportation and change their pollution reduction technologies is irrational; in addition, to eliminate these means of transportation from the system could be very expensive, despite the existence of this social aspect. The most realistic scenario to reduce air pollution from outdated vehicles is the use of fuels that do not require any changes to the engine systems. This process has been successful during last few decades in Europe with bioethanol for spark ignition engines (SIE) and fatty acid methyl esters (FAME) for compression ignition engines (CIE) [5-9]. This is based on the quest for renewable energy. On the other hand, it encourages the use of indigenous fuel production resources to boost their economy. However, only a part of retail fuels consist of biological kinds of fuel, and the remaining fuel type is fossil fuels $[10,11]$. This phenomenon is due to the negative influence of biofuels on engine parts [12-14]. In order to improve the renewable proportions of retail fuels or to use pure biofuels in fossil diesel-designed engines, the demand for advanced biofuels has arisen.

The European transportation fleet consists mainly of diesel-using means of transportation (cargo trucks, buses, inland ships, construction site and agricultural machinery, trains and a portion of passenger cars) that use EN 590 diesel fuel with only $5-10 \%$ of FAME (depending on the country) $[15,16]$. Engine and vehicle producers are in negotiations with EU pollution control and prevention organizations about the increase of bioshare in fossil fuels $[17,18]$, and they have strong opinions about what the reasons are for the slowing speed of this "bioprocess". For this reason, advanced diesels are very important for the European transportation fleet. One of the most promising diesels is pure hydrocarbons made from renewable sources, known as Biomass-to-Liquid (BtL), Hydrotreated Vegetable Oil (HVO) or Hydroprocessed Esters and Fatty Acids (HEFA). These fuels are clean hydrocarbons and have similar properties to fossil fuels, but their combustion is cleaner than that of conventional diesel fuel [19-21] and they offer a number of benefits over FAME, such as reduced nitrogen oxide emissions, better storage stability, and better cold properties [22,23]. Advanced biofuels are straight chain paraffinic hydrocarbons that are free of aromatics and sulfur and have a high cetane number [22].

Compared with fossil diesel, as well with FAME, advanced biodiesels have obviously promising features, such as better low temperature properties (cold filter plugging point, pour and cloud point), and high value and cetane number [24,25]. Compared with fossil diesel, advanced biodiesel has one main difference compared to FAME biodiesel, namely, its comes from a renewable source. Advanced biodiesel is free of oxygen, which causes ignition delay; furthermore, it forms higher heat release peaks in the premixed combustion phase that cause higher temperatures and more $\mathrm{NO}_{\mathrm{x}}$ in the exhaust [26]. However, attention must be paid to the ratio of the density and the heating value of the advanced biodiesel. Some producers have demonstrated that the numbers of both these parameters are promising; the heating value is higher than that of any ultralow sulfur diesel, and low-density fuel has the advantage of being mixable with heavy fuels. However, low density is not a great advantage alone; fuel mass consumption tests in the engine can show promising results, but with low density, the results of the fuel volumetric consumption can provide a totally opposite view of the results. It could be that the higher heating value will not compensate for the influence of low density. It should be noted that each vehicle owner pays at the retail fuel gas station for the fuel volume but not for its mass.

Advanced fuels for CIE are well known in scientific research areas: BtL (or Gas/Coal-to-Liquid) made by the Fischer-Tropsch method $[27,28]$ and other clean hydrocarbon diesel HVO made by eliminating oxygen from the biomass [23,29]. However, the marketing area shows an opposite data when compared with the scientific field. It is clear that fuel production based on the Fischer-Tropsch technology or catalytic hydrogenolysis is much more expensive than that obtained from the crude oil refinery. At any rate, businesses are addressing this issue successfully-a few market level projects can be found, such as the Finnish company NESTE project with their retail HVO fuel, British Airways with its biojet fuel (GreenSky project), and other smaller projects [30]. 
The investigated fuel known as NESTE NexBTL is a relatively new renewable fuel for CIE. NESTE NexBTL is $100 \%$ produced from renewable raw materials by a patented vegetable oil refining process [31]. Plant oils are converted into alkanes via direct catalytic hydrogenolysis. This process removes oxygen from the plant oil, making this oil more similar to a petroleum diesel fuel than to a traditional transesterified FAME biodiesel that contains oxygen [13,32]. Except for density NexBTL meets all the requirements of the European standard EN 590 for a diesel fuel. In September 2016, only a few countries, such as Finland, Lithuania, Latvia, northwestern Russia and Canada offered retail blends of NexBTL and a conventional NESTE diesel fuel known as "Pro Diesel" [33,34]. A comparison of HVO fuel mixtures and the requirements of the EN 590 standard are presented in Table 1.

Table 1. The comparison of the different HVO (Hydrotreated Vegetable Oil) fuel mixtures and pure HVO to the requirements of standard EN 590 [34].

\begin{tabular}{ccc}
\hline Properties & \multicolumn{2}{c}{ Fuel } \\
\cline { 2 - 3 } & HVO (NexBTL100) & EN 590 Standard Requirements \\
\hline Kinematic viscosity, $\mathrm{mm}^{2} / \mathrm{s}$ & $2.9-3.5$ & $2.0-4.5$ \\
Density at $40{ }^{\circ} \mathrm{C}, \mathrm{kg} / \mathrm{m}^{3}$ & $775-785$ & $820-845$ \\
Water content acc. CF, $\%$ & 0.0020 & Max. 0.02 \\
Cetane number & $84-99$ & Min. 51 \\
Lower heating value, $\mathrm{MJ} / \mathrm{kg}$ & $\sim 44$ & $\sim 43$ \\
\hline
\end{tabular}

The results in Table 1 show that the main properties of HVO and its mixtures with diesel fuel fulfil all the EN 590 standard requirements except for the density requirements. This difference is strongly dependent on the chemical properties of the HVO fuel because light molecular mass hydrocarbons dominate in this fuel.

Pro Diesel consists of approximately 15-60\% (by vol., mainly depends on the season) of NexBTL, and the remainder is diesel fuel [34,35]. "Pro Diesel" meets the standard EN 590 and the standard of the Worldwide Fuel Charter (WWFC) with higher requirements as well. "Pro Diesel", with approximately $15 \%$ of NexBTL, was previously studied by some of the authors of this article [25].

The objective of this research was to compare the combustion, energy and emission parameters at various concentrations of hydrotreated vegetable oil in blends with diesel fuel. Noticeable and mostly positive changes in the engine performance indicators have been observed. The demand for different compositions of NexBTL and diesel fuel blends research has arisen due to the positive effect the $15 \%$ of NexBTL in Pro Diesel achieved in the previous research [34].

The NESTE branch company JSC "NESTE Lietuva" in Lithuania ensured the possibility to obtain a pure NexBTL that has been used in forming different composition blends with pure diesel fuel (without a FAME blending component). Seven different blends that consist of $10-85 \%$ NexBTL, as well as pure NexBTL, were tested in a passenger car diesel engine dyno stand. Before this experiment, the main physical and chemical properties were determined using laboratory equipment. Engine performance indicators were compared among all of the NexBTL fuels based on the reference results of pure diesel fuel.

\section{Materials and Methods}

\subsection{Fuel Testing Equipment}

Physical and chemical properties of the tested fuels were analyzed at the Klaipeda University Open Access Centre for Marine Research (KU OACMR) Marine Chemistry laboratory. Fuel properties were measured 3-4 times and the average values were estimated. Table 2 shows the measured parameters, equipment used, accuracy and detection methods. 
Table 2. The accuracy of fuel property measurement equipment.

\begin{tabular}{|c|c|c|c|}
\hline Parameter & Device & Method & Accuracy \\
\hline $\begin{array}{c}\text { Gross heating value, } \mathrm{J} / \mathrm{g} \\
\text { Lower heating value } L H V, \mathrm{~J} / \mathrm{g}\end{array}$ & IKA C 5000 calorimeter & DIN 51900-2 & $130 \mathrm{~J} / \mathrm{g}$ \\
\hline Flash point, ${ }^{\circ} \mathrm{C}$ & FP93 5G2 Pensky-Martens analyzer & ISO 2719 & $0.03^{\circ} \mathrm{C}$ \\
\hline $\begin{array}{c}\text { Dynamic viscosity, } \mathrm{mPa} \cdot \mathrm{s} \\
\text { Kinematic viscosity, } \mathrm{mm}^{2} / \mathrm{s} \\
\text { Density, } \mathrm{g} / \mathrm{cm}^{3}\end{array}$ & $\begin{array}{c}\text { Anton Paar SVM 3000/G2 } \\
\text { Stabinger Viscometer }\end{array}$ & ASTM D7042 & $\begin{array}{c}0.1 \% \\
0.1 \% \\
0.0002 \mathrm{~g} / \mathrm{cm}^{3}\end{array}$ \\
\hline Oxidative stability, min. & PetroOXY analyzer & EN 16091 & $0.1 \%$ \\
\hline $\mathrm{CFPP},{ }^{\circ} \mathrm{C}$ & FPP 5Gs analyzer & EN 116 & $1{ }^{\circ} \mathrm{C}$ \\
\hline Pour point, ${ }^{\circ} \mathrm{C}$ & CPP 5Gs analyzer & ISO 3016 & $3{ }^{\circ} \mathrm{C}$ \\
\hline Water content, $\%$ mass & Aquamax KF Coulometric analyzer & ISO 12937 & $0.0003 \%$ \\
\hline $\begin{array}{l}\text { Cetane number } \\
\text { Cetane index }\end{array}$ & PetroSpec analyzer & $\begin{array}{l}\text { ASTM D613 } \\
\text { ASTM D4737 }\end{array}$ & $\begin{array}{l}0.05 \% \\
0.05 \%\end{array}$ \\
\hline Sulfur, $\%$ mass & $\begin{array}{l}\text { IKA C } 5000 \text { calorimeter, muffle } \\
\text { furnace, scales }\end{array}$ & GOST 3877 & $0.04 \%$ \\
\hline
\end{tabular}

\subsection{Engine Testing Equipment}

Audi 1.9 TDI (Turbocharged Direct Injection) engine (Audi-VW, Germany) tests were performed at the Internal Combustion Engines laboratory of the Automobile Transport Department, Faculty of Transport Engineering of Vilnius Gediminas Technical University (VGTU). A 1.9 TDI diesel engine (1Z type) with an Electronic Control Unit (ECU)-controlled BOSCH VP37 (Bosch, Germany) distribution type rotary fuel pump and turbocharger was used for the tests. The start of the injection (SOI) was controlled by the ECU and it was a single injection strategy. The main parameters of the diesel engine Audi 1.9 TDI are shown in Table 3.

Table 3. Main parameters of a VW-Audi 1Z 1.9 TDI diesel engine.

\begin{tabular}{cc}
\hline Parameter & Value \\
\hline Displacement $\left(\mathrm{cm}^{3}\right)$ & 1896 \\
Number of cylinders & $4 / \mathrm{OHC}$ \\
Compression ratio & 19.5 \\
Power $(\mathrm{kW})$ & $66(4000 \mathrm{rpm})$ \\
Torque $(\mathrm{Nm})$ & $180(2000-2500 \mathrm{rpm})$ \\
Bore $(\mathrm{mm})$ & 79.5 \\
Stroke $(\mathrm{mm})$ & 95.5 \\
Fuel injection & Direct injection (single) \\
Fuel injection-pump design & Axial-piston distributor injection pump \\
Nozzle type & Hole-type \\
Nozzle and holder assembly & Two-spring \\
Nozzle opening pressure (bar) & $190-200$ \\
\hline
\end{tabular}

A scheme of the laboratory equipment is shown in Figure 1. A KI-5543 engine brake stand (GOSNITI, Russia) was used for the brake torque $\left(M_{B}\right)$ load and crankshaft speed determinations. The torque measurement error was $\pm 1.23 \mathrm{Nm}$. The hourly fuel consumption $B_{f}$ was measured by a SK-5000 electronic scale (A\&D, Germany) and a stopwatch, with an accuracy of $B_{f}$ determination of $0.5 \%$. The pollutants in the exhaust gas were measured using AVL DICOM 4000 gas analyzers (AVL, Austria) (for $\mathrm{CO}, \mathrm{CO}_{2}, \mathrm{HC}$, and $\mathrm{NO}_{\mathrm{x}}$ ) and an AVL DiSmoke (AVL, Austria) (for smoke opacity). The CO measuring range was $0-10 \%$ (vol.), resolution $0.01 \%$; the $\mathrm{CO}_{2}$ measuring range was $0-20 \%$ (vol.), resolution $0.1 \%$; the $\mathrm{HC}$ measuring range was $0-20,000 \mathrm{ppm}$ (vol.), resolution $1 \mathrm{ppm}$; the $\mathrm{NO}_{\mathrm{x}}$ measuring range was 0-5000 ppm (vol.), resolution $1 \mathrm{ppm}$; the absorption (K-Value) measuring range was $0-99.99 \mathrm{~m}^{-1}$, resolution $0.01 \mathrm{~m}^{-1}$. 


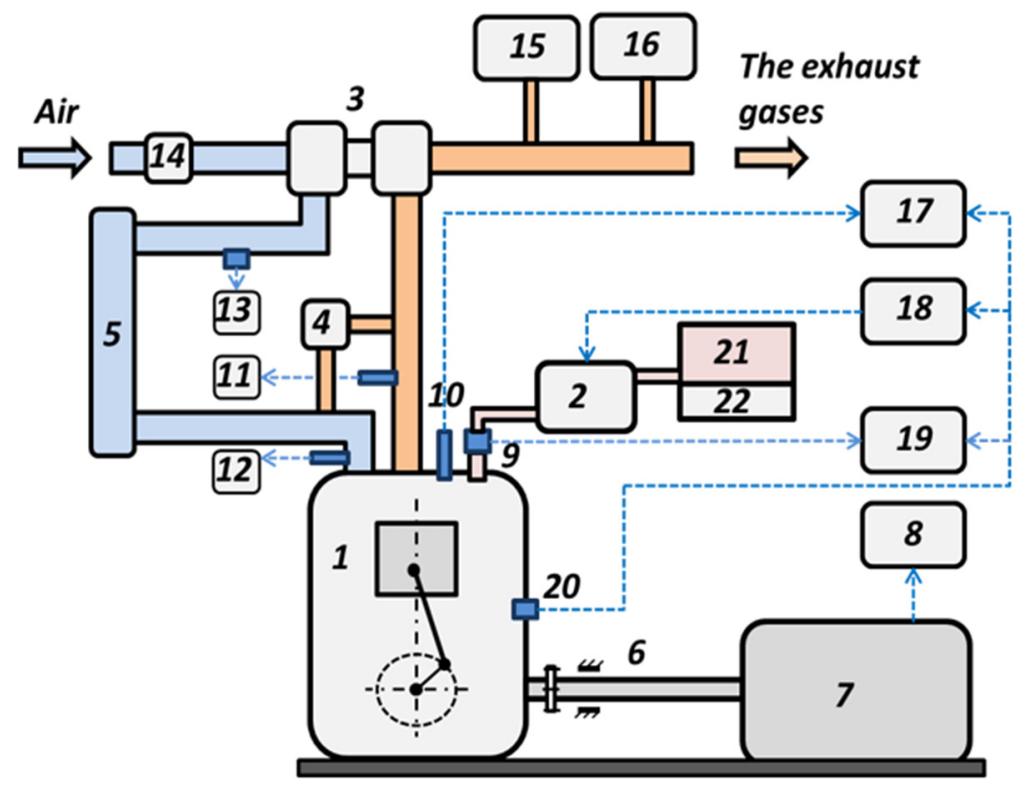

Figure 1. The scheme of engine testing equipment: $1-1.9$ TDI engine; 2 -high pressure fuel pump; 3-turbocharger; 4-EGR (Exhaust Gas Recirculation) valve; 5-air cooler; 6-connecting shaft; 7-engine load plate; 8 - engine torque and rotational speed recording equipment; 9-fuel injection timing sensor; 10—cylinder pressure sensor; 11-exhaust gas temperature meter; 12 -intake gas temperature meter; 13-air pressure meter; 14-air mass meter; 15-exhaust gas analyzer; 16-opacity analyzer; 17-cylinder pressure recording equipment; 18-fuel injection timing control equipment; 19-fuel injection timing recording equipment; 20—crankshaft position sensor; 21—fuel tank; 22—fuel consumption measure equipment.

In-cylinder pressure $(p)$ was recorded by an AVL GH13P piezo sensor (AVL, Austria) (sensitivity $16 \mathrm{pC} / \mathrm{bar}$, linearity of FSO $\leq \pm 0.3 \%$ ), which is integrated in the preheating plug and was recorded using an AVL DiTEST DPM 800 amplifier (AVL, Austria) (input range 6000 pC, signal ratio $1 \mathrm{mV} / \mathrm{pC}$, overall error complete temperature range $1 \%$ ). The intake air mass flow meter measured by a $\mathrm{BOSCH}$ HFM 5 (Bosch, Germany) with an accuracy of $2 \%$. Intake manifold pressure was measured with a Delta OHM HD 2304.0 pressure gauge (Delta OHM, Italy). The sensor of the TP704-2BAI device, with an error of $\pm 0.0002 \mathrm{MPa}$, was mounted ahead of the intake manifold. As the exhaust and intake gases temperature meter, a K-type thermocouple (accuracy $\pm 1.5^{\circ} \mathrm{C}$ ), was used.

\subsection{Fuels and Test Conditions}

Experiments were carried out using pure diesel fuel and various content blends of hydrotreated vegetable oil (HVO), which the NESTE company calls Renewable Diesel NexBTL. NexBTL fuel quality is equal to the synthetic Fischer-Tropsch BTL fuel [20,34]. The content of NexBTL varied from $0 \%$ to $85 \%$ by volume in the fuel blends (NexBTL0, NexBTL10, NexBTL20, NexBTL30, NexBTL40, NexBTL50, NexBTL70, NexBTL85), and the pure NexBTL (NexBTL100) was also tested. The fuel mixtures NexBTL10, NexBTL20, NexBTL70 and NexBTL85 were obtained by mixing pure diesel and NexBTL100. The fuel Mixtures NexBTL30, NexBTL40, NexBTL50 are available in the NESTE company's petrol stations to purchase as Pro Diesel. In the summer, the concentration of NexBTL is approximately $30 \%$, in spring, it is approximately $40 \%$, and in winter, it is approximately $50 \%$. The results of all these kinds of fuels were compared based on the diesel fuel results.

Experiments were carried out at two engine speeds: $n=2000$ and $n=2500 \mathrm{rpm}$. The brake torque $\left(M_{B}\right)$ load was 30, 60, 90 and $120 \mathrm{Nm}$. These speeds correspond to the values of brake mean effective pressures $(B M E P)$ of $0.2,0.4,0.6$ and $0.8 \mathrm{MPa}$, respectively. These values represent $16.6 \%, 33.3 \%$, $50.0 \%, 66.6 \%$ of the engine's maximum torque (Table 3). Tests for the engine coolant temperature were conducted at $87 \pm 2{ }^{\circ} \mathrm{C}$, and the oil temperature was tested at $100 \pm 2{ }^{\circ} \mathrm{C}$. The exhaust gas recirculation 
(EGR) system was disabled during the tests because it helps to better assess the influence of NexBTL on engine parameters. To investigate the influence of blends with a different content of NexBTL on the engine operational parameters, the experiments were carried out while retaining diesel fuel for the fuel injection timing. The advancement of the fuel injection start could be relevant to the direction continuing chain of NexBTL research because NexBTL has relatively high cetane number, and it is free of oxygen.

\subsection{Simulation Tools}

The analysis of the heat release characteristics is very important in cases when fuels with a significant difference between their cetane numbers are used in a diesel engine. AVL BOOST simulation software was used for the combustion process $(d Q / d \varphi$ and $d p / d \varphi$ characteristics) analysis. The maximum values of $d Q / d \varphi$ and $d p / d \varphi$ represent the thermal and mechanical load to boundary cylinder parts very well. One of the subprograms of BOOST, called BURN, calculates the rates of heat release relatively simply. This subprogram is used for the simulation of heat transfer and release and of changes in in-cylinder pressure and temperature, etc., based on experimental studies. One important characteristic of heat release and pressure rise was calculated by a BURN subprogram using measured in-cylinder pressure data.

\section{Results}

\subsection{Fuel properties}

The numbers of the main properties of the tested fuels (and blends) are given in Appendix A. The scatter of determined numbers of the main physical and chemical properties shows a relatively strong dependence on the percent of NexBTL in the fuel blends (Figures 2-4). This fact provides a good basis for the analysis and assessment of engine performance parameters. The density of the fuels was analyzed at $40{ }^{\circ} \mathrm{C}$, which was different from the mentioned test conditions in the NexBTL and diesel fuel official certificates. However, the densities of pure diesel fuel and pure NexBTL were determined at $15{ }^{\circ} \mathrm{C}$ to ensure that the results at $40{ }^{\circ} \mathrm{C}$ are adequate for those at $15{ }^{\circ} \mathrm{C}$. The determined densities were $0.7814 \mathrm{~g} / \mathrm{ml}$ for NexBTL and $0.8469 \mathrm{~g} / \mathrm{ml}$ for pure diesel fuel (these values were confirmed in another laboratory as 0.7779 and $0.8441 \mathrm{~g} / \mathrm{ml}$, respectively); official certificates show $0.7798 \mathrm{~g} / \mathrm{ml}$ for NexBTL and $0.8441 \mathrm{~g} / \mathrm{ml}$ for pure diesel fuel [36]. The mismatch of density values reaches up to $0.2 \%$. A brief description of the researched physical and chemical properties could be started with a positive fact-all these parameters have a smooth change when the ratio of NexBTL and diesel fuel changes (Figures 2-5). It goes without saying that NexBTL, with lower viscosity, density and water content values, makes these parameters lower in blends with diesel fuels. Lower water content (Figure 3) in fuels is a positive feature due its negative influence on the combustion process and the surfaces of fuel system parts.

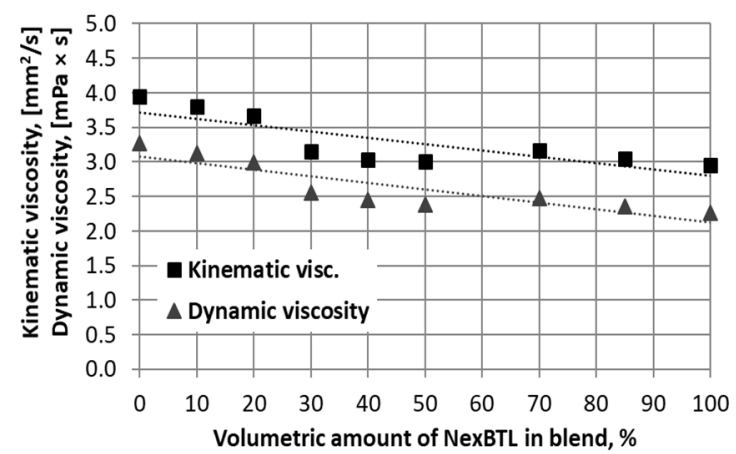

Figure 2. Dependence of the dynamic and kinematic viscosities $\left(40^{\circ} \mathrm{C}\right)$ on percentage of NexBTL in fuel blends. 


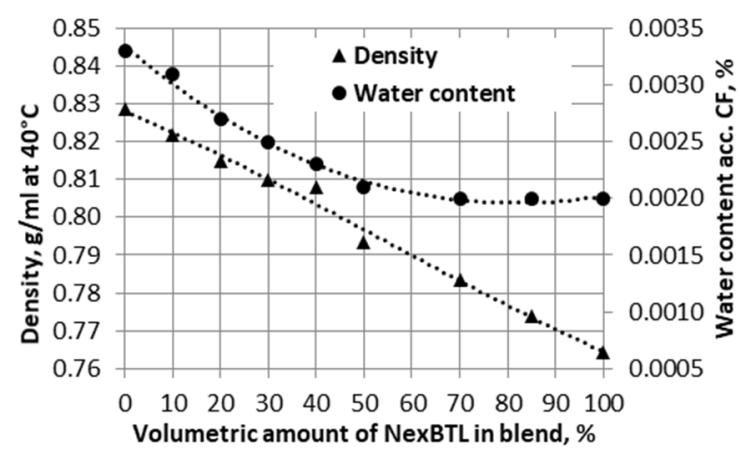

Figure 3. Dependence of the density $\left(40^{\circ} \mathrm{C}\right)$ and water content on the percentage of NexBTL in fuel blends.

However, the density and viscosity here are controversially assessed due to their negative and positive features. Low viscosity is good for spray (as well for atomization) characteristics, especially when mixed with heavier fuels, but low viscosity could result in leakage and low-quality spray in old low fuel pressure diesel engines. Low density is a positive feature for mixing with heavier fuels as well as viscosity, but usually low density results in a higher mass fuel consumption if it is not compensated by a lower heating value, and a significant increase could be found in volumetric fuel consumption data.

The influence of NexBTL on the cold filter plugging point (CFFP), pour point and cetane number is clearly promising (Figure 4). CFFP (which varies from -10 to $-40^{\circ} \mathrm{C}$ ) and the pour point (which varies from -39 to $-58{ }^{\circ} \mathrm{C}$ ) are the main low-temperature properties, and their increase ensures better fuel use in low-temperature surroundings. Since the cetane number $(\mathrm{CN})$ is very important for the engine cold start, the higher value of $\mathrm{CN}$ allows the engine to start much easier [37]. Together with a better engine cold start feature, the value of $\mathrm{CN}$ has an influence on the combustion process-a higher $\mathrm{CN}$ results in a better fuel ignition in the engine's cylinder and a shorter ignition delay [13]. A higher fuel $\mathrm{CN}$ provides a longer time for the combustion and a better distribution (avoiding high peaks in premixed combustion) of released heat in the combustion process. Usually, the heat release peak of the premixed combustion is reduced, and the peak of the diffusion phase increased when higher $\mathrm{CN}$ fuels are used. A lower heat release peak in the premixed combustion provides for lower nitrogen oxides $\left(\mathrm{NO}_{\mathrm{x}}\right)$ formation, pressure rise and thermal loads for the engine; a higher heat release in the diffusion phase results in lower emission of incomplete combustion products such as HC and PM. However, these features of higher $\mathrm{CN}$ must be proven by engine tests in each case of a different kind of fuel use. This research is provided in the next sections of the article (Section 3.2. Results of combustion process rates and Section 4. Discussion).

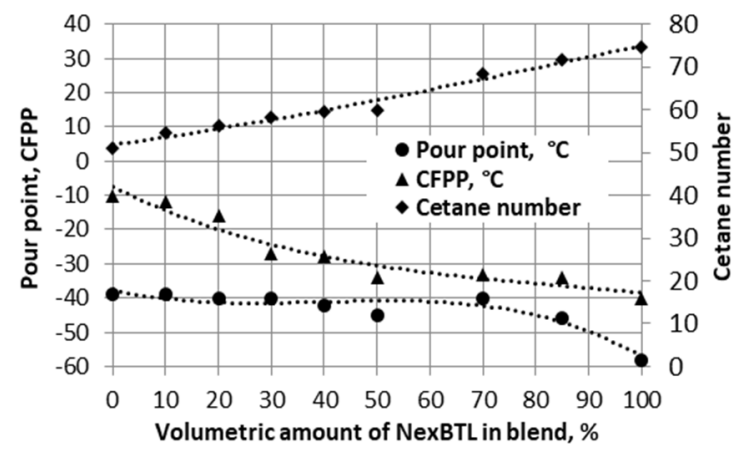

Figure 4. Dependence of the pour point, cold filter plugging point and cetane number on the percentage of NexBTL in fuel blends. 
The increase in the percentage of NexBTL in the blends resulted in their higher heating value (gross and net) and improved oxidative stability (Figure 5). The improved oxidative stability means more time until the physical and chemical properties will start to change. The change in physical and chemical properties has a negative influence for the fuels' quality parameters and engine performance [38,39]. Generally, the amount of specific energy is relevant for using all kind of fuels but especially for the low density fuels which are analyzed here. Just one parameter (despite minor molecular bond type, spray characteristics, and few other changes) in practice, can compensate for energy loss in modified fuel. These changes there were as result from the presence of a lower density, and have a higher heat value [37].

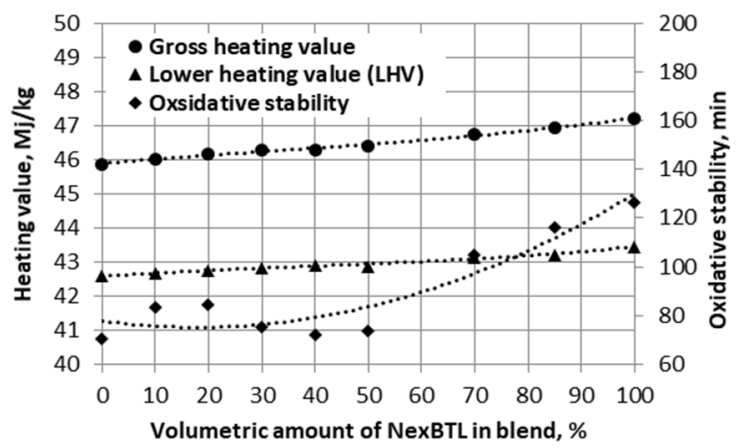

Figure 5. Dependence of the heating value (gross and lower) and improved oxidative stability on the percentage of NexBTL in fuel blends.

This research includes an analogous situation when NexBTL, with lower density and a higher heating value, is gradually mixed with pure diesel fuel. However, it is difficult to decide what will be the result of the engine fuel consumption, knowing only these two parameters and avoiding engine tests. The engine fuel consumption results are presented in Section 4. Discussion.

\subsection{Results of Combustion Process Rates}

Research on heat release characteristics is very important for comparing different kind of fuels with a relatively large difference between $\mathrm{CNs}$. As mentioned before, a higher $\mathrm{CN}$ provides a shorter ignition delay [40] that possibly provides a longer time for the combustion and an increased diffusion combustion (avoiding high peaks in premixed combustion) distribution of heat release in premixed and diffusion-controlled combustion. This feature is relevant especially for fuels such as biodiesel with a low $\mathrm{CN}$, which have combustion characterized by higher $\mathrm{NO}_{\mathrm{x}}$ emission concentration, are influenced by higher heat release values in premixed combustion, have a higher amount of combusted fuel due to lower energy and are chemical compounds [32]. However, NexBTL has a significantly higher CN and ignition delay, which is expected to gradually decline when the amount of NexBTL in the blend gradually increases.

A model of a 1.9 TDI engine was created by AVL Boost software (subprogram BURN) to calculate the characteristics of heat release $(d Q / d \varphi)$ and pressure rise $(d p / d \varphi)$. The BURN subprogram was designed for the heat transfer and release, change in in-cylinder pressure, and temperature simulation based on the experimental studies. The characteristics of heat release and pressure rise were calculated by a BURN subprogram using data of the in-cylinder pressure.

Regimes of maximum tested load point $\left(M_{B}=120 \mathrm{Nm}\right)$ at engine speeds of 2000 and $2500 \mathrm{rpm}$ were chosen for the combustion parameter analysis due to the stability of the engine work because the pressure indication is very sensitive for the instability. The SOI was controlled by the ECU: for $n=2000 \mathrm{rpm}$ and $M_{B}=120 \mathrm{Nm}, S O I=\sim 4$ Crank Angle Degrees (CAD), Before Top Dead Center (BTDC); for $n=2500 \mathrm{rpm}$ and $M_{B}=120 \mathrm{Nm}, S O I=\sim 8$ CAD BTDC. A single fuel injection strategy was used. The data of in-cylinder (Figure $6 a, b$ ) pressure did not show obvious changes and no significant trends have been found by changing the amount of NexBTL in the fuel blend. Practically, 
the pressure trace for each fuel is very similar to the others, and the difference could be explained by a measurement error and pressure jumps in the high pressure range. However, a few remarks should be noted. There may be a tendency for higher pressure in the kinetic (premixed) combustion phase to be achieved by using the engine with a lower amount of NexBTL, while in the final (diffusion) combustion phase, higher pressure is reached when the engine is fueled with more NexBTL in the fuel mixture. This phenomenon means that, by using fuel with more NexBTL in the fuel mix, heat is released at a lower intensity in the premixed combustion phase, and more heat is released during the diffusion combustion. This trend is more pronounced at $n=2500 \mathrm{rpm}$ and $M_{B}=120 \mathrm{Nm}$. Higher pressure in the diffusion combustion phase is possible because the NexBTL fuel volume BSFC is 4-6\% higher than the diesel fuel consumption (Figure 9a,b), and the higher fuel quantity is sprayed and burns in this combustion phase. Lower pressure in the premixed combustion phase could be justified by the high CN of NexBTL100. However, not all results confirm this position. Similar results were obtained by Millo et al. during passenger car engine tests, Niemi et al. who tested AGCO POWER 44 AWI engine (Valtra, Finland) and others [41,42]. The fact of a slight or negligible change in engine in-cylinder pressure could be assessed in two ways. One of the ways is that new kinds of fuels have no significant change in the most important parameter in the combustion process, but on the other hand, this fuel can be used in engine fleets that are currently in use without significant changes to the combustion process or to the reliability parameters they are designed for.
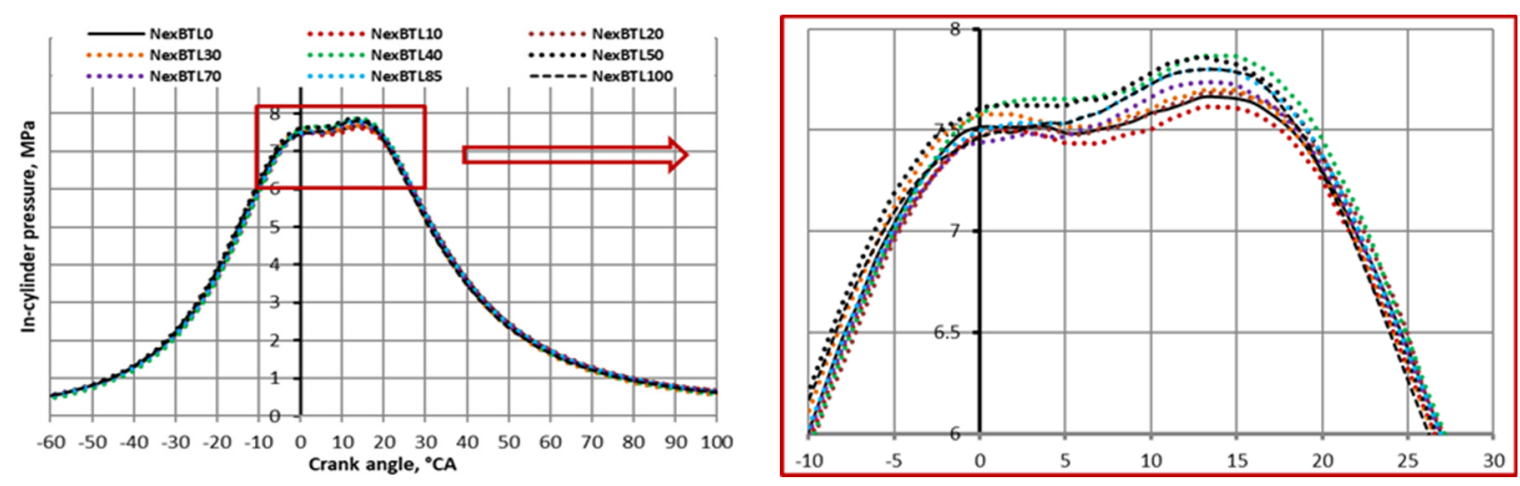

(a)
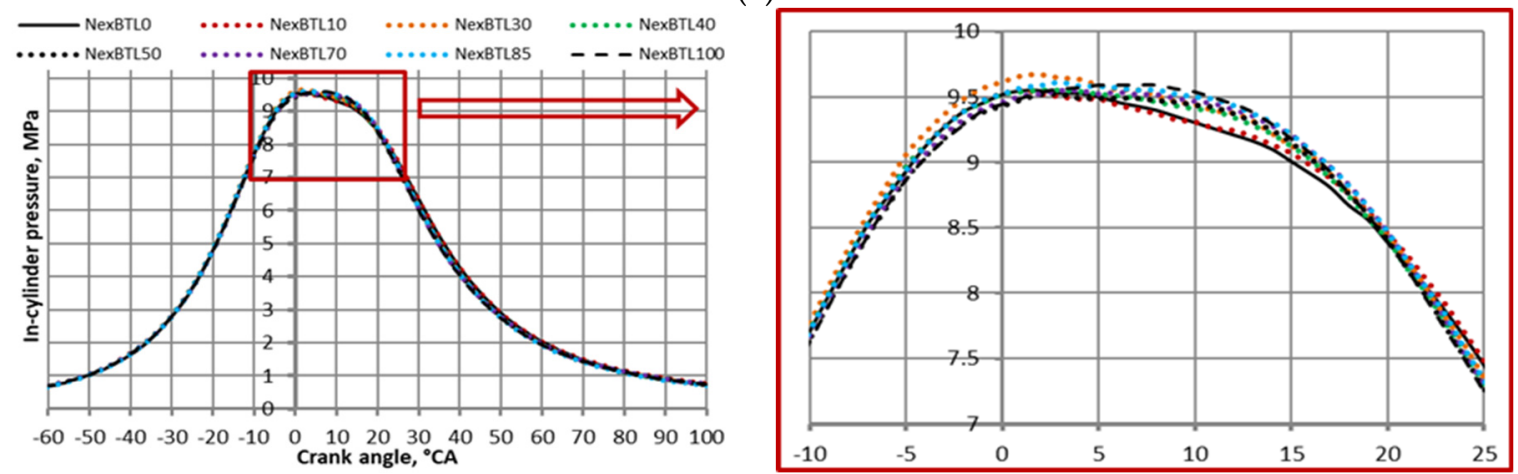

(b)

Figure 6. In-cylinder pressure characteristics: (a) $n=2000 \mathrm{rpm}, M_{B}=120 \mathrm{Nm}$; (b) $n=2500 \mathrm{rpm}$, $M_{B}=120 \mathrm{Nm}$.

Pressure traces (or indicator diagrams) are very important, but heat release characteristics are more valuable for the analysis of the combustion (heat release) process [37,43]. These characteristics are provided as the rate of heat release $(R O H R)$, which is dependent on ${ }^{\circ} \mathrm{CA}$ (Figure $\left.7 \mathrm{a}, \mathrm{b}\right)$. No significant changes were observed, and the differences between values are only up to $1.5 \mathrm{~J} /{ }^{\circ} \mathrm{CA}$; the higher difference resulted from a delayed or advanced combustion process. This finding is seen very clearly in Figure 7a, especially when comparing NexBTL0 with NexBTL100 $\left(n=2000 \mathrm{rpm}, M_{B}=120 \mathrm{Nm}\right)$, 
and the NexBTL100 combustion is advanced due to its higher CN (maximum ROHR is approximately $1.0 \mathrm{~J} /{ }^{\circ} \mathrm{CA}$ lower) and NexBTL0 is the opposite. In the single cases, the shorter combustion could be stated due to a better, smoother oxidation process. However, the higher engine speed test regime ( $n=2500 \mathrm{rpm}, M_{B}=120 \mathrm{Nm}$ ) can be characterized by the same remarks related with the advance or delay of the combustion process (NexBTL maximum ROHR is approximately $0.9 \mathrm{~J} /{ }^{\circ} \mathrm{CA}$ lower). Heat release rates and other combustion parameters (duration, start of heat release, etc.) highly depend on the amount of combustion processes during the same time. In engine terms, this parameter depends on the engine speed; a higher speed allows less time for the fuel oxidation process, and a lower speed shows the opposite trend. For this reason, average speed regimes are more informative than high speed regimes.
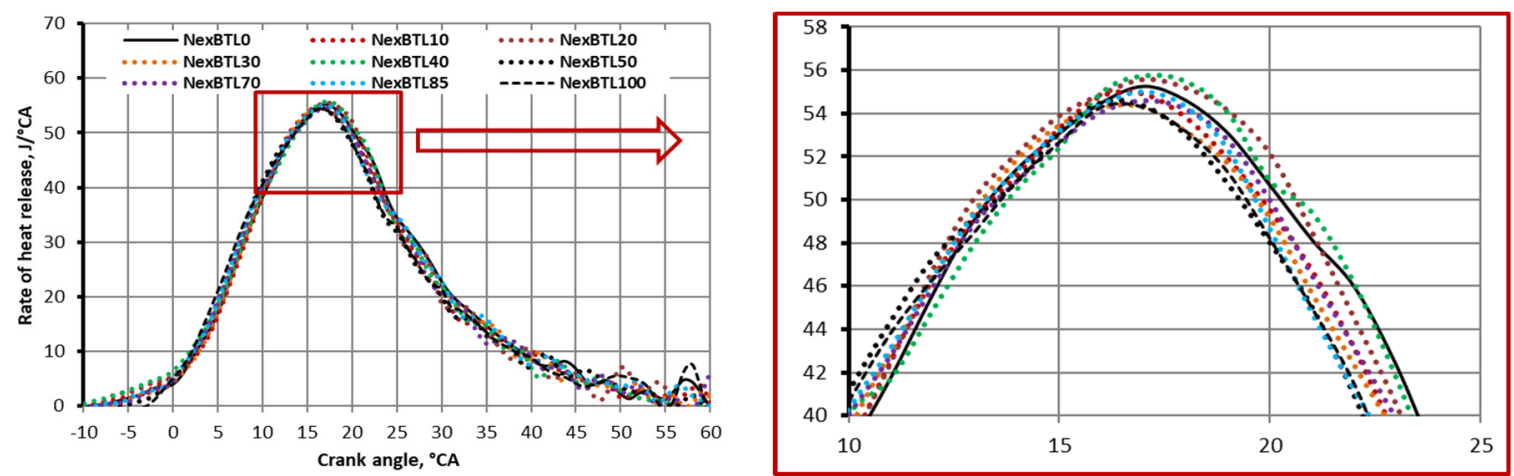

(a)
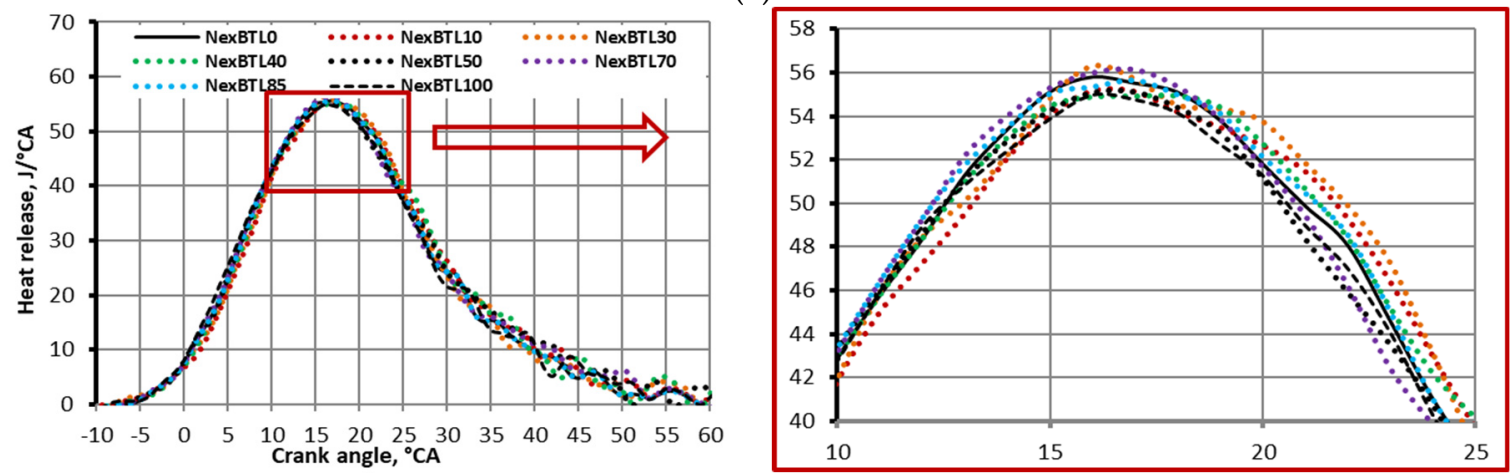

(b)

Figure 7. Rate of heat release characteristics: (a) $n=2000 \mathrm{rpm}, M_{B}=120 \mathrm{Nm}$; (b) $n=2500 \mathrm{rpm}, M_{B}=$ $120 \mathrm{Nm}$.

A similar situation can be observed with a high load regime compared with low and average load regimes. The combustion process at a high load regimes is characterized as a diffusion-controlled combustion, and the premixed phase is negligible. The combustion process at low and average load regimes is characterized as premixed and diffusion control $[39,43,44]$. It is well known that using high $\mathrm{CN}$ fuel instead lower $\mathrm{CN}$ fuel is optimal; the main phenomenon of change appears in the premixed phase with further influence on parameter changes, such as a rise of premixed temperature and further $\mathrm{NO}_{x}$ formation [45-47].

A detailed study of heat release characteristics and parameters of nine different fuels in various load and speed regimes could fill several articles. In addition, research related to the analysis of heat release characteristics has to be much more concentrated on the pressure and heat release parameters and their changes. However, in this complex research (fuel properties determination, parameter analysis of combustion, energy and pollution) these ROHR characteristics (Figure 7a,b) have been used to evaluate the detection of significant changes using different fuels. 


\section{Discussion}

Parameters such as fuel consumption, thermal efficiency and pollution rates were calculated from the measured results and analyzed using engine test results. Rates of nitrogen oxides $\left(\mathrm{NO}_{\mathrm{x}}\right)$, hydrocarbons $(\mathrm{HC})$, smoke opacity $(\mathrm{SM})$, carbon dioxide $\left(\mathrm{CO}_{2}\right)$, break specific fuel consumption $(B S F C)$ and brake thermal efficiency (BTE) were determined.

Usually, fuel consumption data are provided in research papers as a mass dimension rate, such as $B S F C \mathrm{~kg} / \mathrm{kWh}$ or $\mathrm{kg} / \mathrm{h}$ [48-50]. However, volumetric consumption is much more valuable for consumers and an economic analysis. It appears that the change between the volumetric and mass fuel consumption is relevant when lower density fuels are compared with higher density fuels. Fuels such as the NexBLT or other HVO with lower density [51,52] can show better mass fuel consumption rates, but volumetric rates can be opposite.

Despite an investigation of BSFC dependence on the NexBTL percentage in the fuel blends, one of the main targets was to investigate the volumetric and mass fuel consumption, in order to assess the advantages and shortages between pure diesel fuel and pure NexBTL, which is characterized by a lower density and higher heating value. Figure $8 a, b$ and Figure $9 a, b$ have been used for the assessment. A "zero line" represents pure diesel, and the columns show the relative deviation of mass (Figure 8a,b) and volumetric BSFC (Figure 9a,b) in four engine load regimes $\left(M_{B} 30 \mathrm{Nm}, 60 \mathrm{Nm}, 90 \mathrm{Nm}\right.$ and $120 \mathrm{Nm}$ ) for each percentage of NexBTL in a fuel blend.

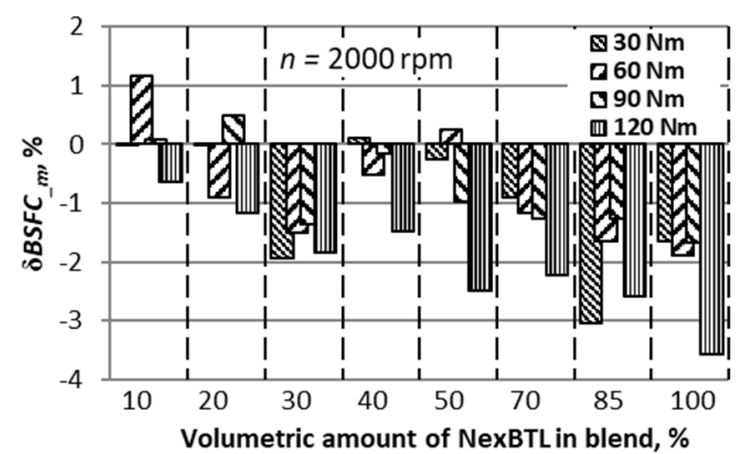

(a)

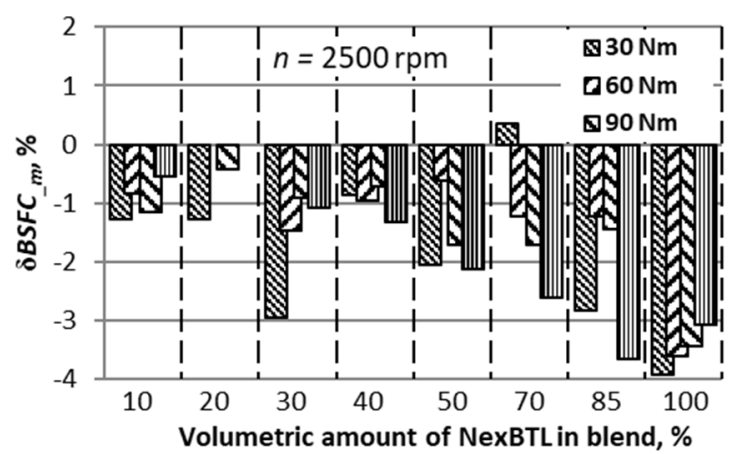

(b)

Figure 8. Relative deviation of BSFC according to mass fuel consumption [g/kWh]: (a) $n=2000 \mathrm{rpm}$; (b) $n=2500 \mathrm{rpm}$.

Both figures show obvious differences between the pure diesel and blends with NexBTL. Both speed regimes are characterized by a decrease of up to about $3.5 \%$ of the $B S F C_{-} m$ (mass). Only a few points are above the zero line, which mainly have negligible relative deviation valuesf. When assessing the fuel consumption by mass, a relatively small (small in this research) percentage (10-30\%) of NexBTL reduces the fuel consumption up to $2-3 \%$ already. Similar results, which are not often conformable, were achieved in other papers [22,43]. Therefore, NexBTL and the blends with it are promising assessing rates of fuel mass consumption. However, an opposite view was found in the assessment of volumetric fuel consumption rates (Figure $9 a, b$ ). The results of the volumetric BSFC_V show an increase of up to approximately $6 \%$ of the fuel consumption in both speed regimes and mainly in all load points. The main reason is the NexBTL density, which is approximately $7.7 \%$ lower than diesel (Appendix A). 


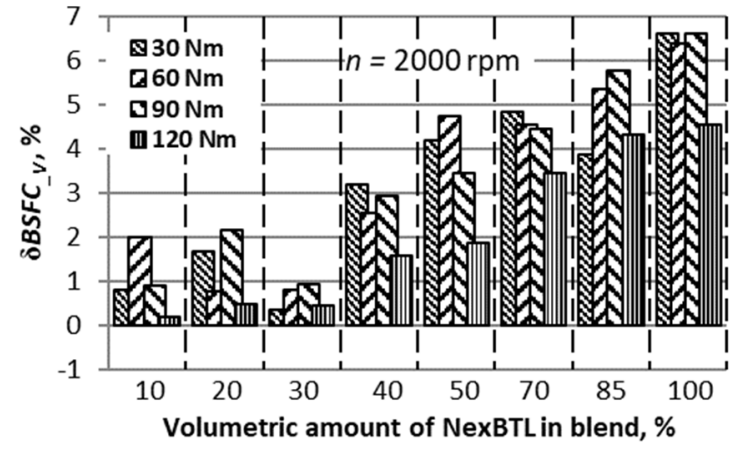

(a)

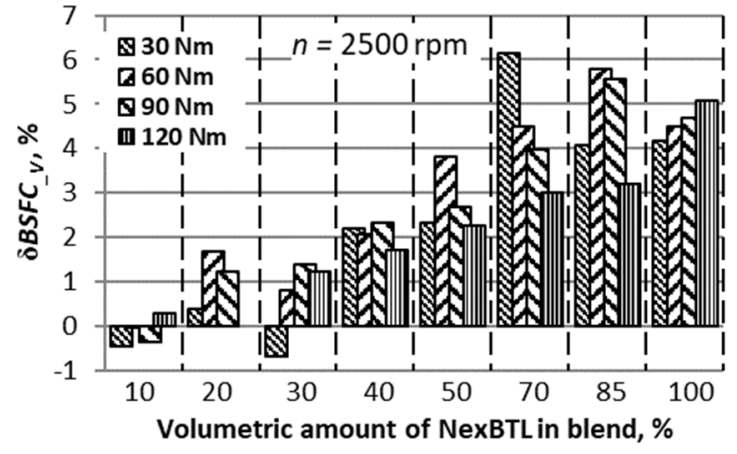

(b)

Figure 9. Relative deviation of $B S F C$ according to volumetric fuel consumption [ml $/ \mathrm{kWh}]$ : (a) $n=2000 \mathrm{rpm}$; (b) $n=2500 \mathrm{rpm}$.

The trend of increased fuel consumption can be seen very well, and it has a strong dependency on the percentage of NexBTL in the blends. The assessment clarified that the use of NexBTL and its blends in a direct injection diesel engine with an electronically controlled distribution type fuel pump has better fuel mass consumption rates, but the volumetric consumption is higher than pure diesel fuel due to lower density. In addition, it was determined that the energy content in NexBTL is disproportionate to compensate for the loss of density.

Thermal efficiency, as well as the fuel consumption rates, is very important. These parameters show that effectively fuel energy is converted into mechanical energy during the combustion process in an engine. As usual $[37,53,54]$, a parameter called break thermal efficiency (BTE) is used for the efficiency assessment. BTE is calculated using values of $B S F C_{-} m$ and the lower heating value (LHV) of the tested fuels. The $L H V$ of NexBTL in comparison with pure diesel is approximately $2.0 \%$ higher (Appendix A). The difference (not a relative deviation) between pure diesel and NexBTL density values has no influence on BTE at all. The change of BTE depends on the amount of NexBTL in a blend, as presented in Figure 10a,b.

The range of $B T E$ increase $0.5-1.4 \%$ includes nearly all the results. The results do not show any tendencies related to BTE dependency on the amount of NexBTL in the blend. Rather, the BTE change is nearly constant or only slightly depends on the load or speed regime. Similar results have been reported in previous research by the authors of this paper [35].

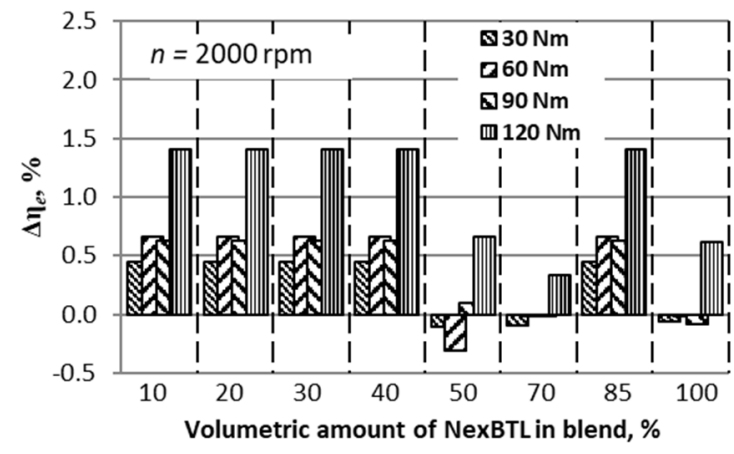

(a)

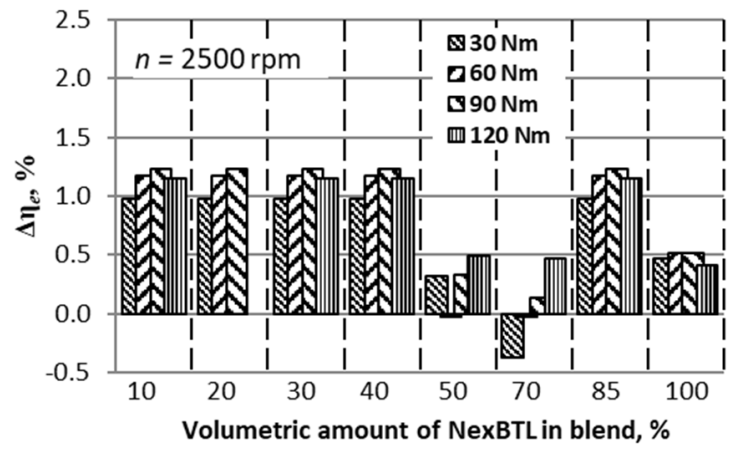

(b)

Figure 10. Difference in BTE: (a) $n=2000 \mathrm{rpm}$; (b) $n=2500 \mathrm{rpm}$.

Parameters such as $\mathrm{CO}, \mathrm{CO}_{2}, \mathrm{NO}_{\mathrm{x}}, \mathrm{HC}$ and $\mathrm{SM}$ have been measured during engine tests. However, some of these measurements are worth analyzing graphically. The change in carbon monoxide was negligible when the NexBTL proportion in the fuel blend increased, but an improvement of $5 \%$ was observed in heavy duty engine research [25]. In addition, the change in carbon dioxide was up to approx. $0.3-0.35 \%$, and the maximum reduction was achieved when the NexBTL volume increased up 
to $85-100 \%$ of the fuel. However, when using NexBTL or another HVO, the general well-to-wheel $\mathrm{CO}_{2}$ emissions in the atmosphere are up to 10 times lower than fossil fuels because it is not made from fossil sources but from renewable sources $[20,55]$ that use $\mathrm{CO}_{2}$ during growth.

A visible change has been observed when analyzing other pollution compounds, such as $\mathrm{NO}_{\mathrm{x}}$, $\mathrm{HC}$ and SM. The reduction in $\mathrm{NO}_{\mathrm{x}}$ is clearly seen in both engine speed regimes (Figure 11a,b); however, it must be separated into two groups-concentration change at low load $\left(M_{B}=30 \mathrm{Nm}\right)$ and average-high load regimes $(60 \mathrm{Nm}, 90 \mathrm{Nm}$ and $120 \mathrm{Nm})$. The results at low load regimes represent the decreasing diffusion of combustion, while the amount of NexBTL increased, the concentration of $\mathrm{NO}_{x}$ varied in approximately the 3-20\% range at low load regimes. However, the least load regimes showed a $\mathrm{NO}_{x}$ reduction of approximately $0.5-7.5 \%$, and the maximum reduction values were achieved by a high NexBTL concentration presence in the fuel blend. This fact represents the positive influence of an increase in the NexBTL percentage in order to reduce the $\mathrm{NO}_{\mathrm{x}}$ concentration in the exhaust gas. The decreased $\mathrm{NO}_{x}$ concentration could be influenced by a higher cetane number (Figure 4 or Appendix A) and a changed chemical composition [55,56]. Furthermore, these factors changed the parameters and characteristics of the combustion process. Higher $\mathrm{CN}$ fuels have a shorter ignition delay, which makes combustion a more increased diffusion combustion and avoids the high peak temperature in premixed combustion. Temperature reduction in the combustion chamber is related to a lower heat release in the premixed phase, which directly influenced and reduced $\mathrm{NO}_{\mathrm{x}}[44-46,57]$.

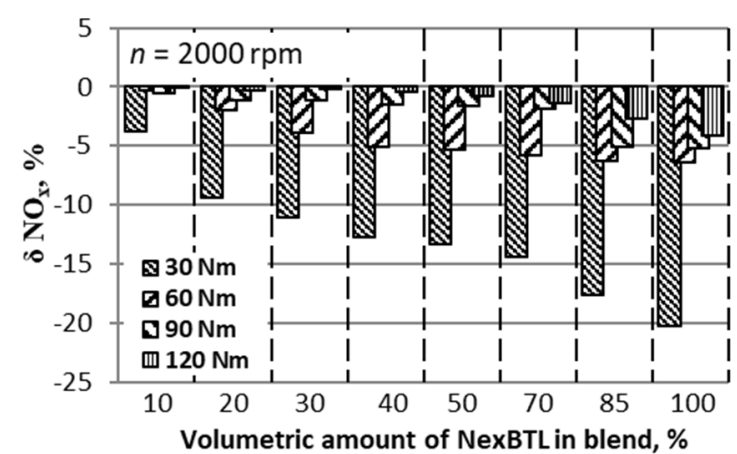

(a)

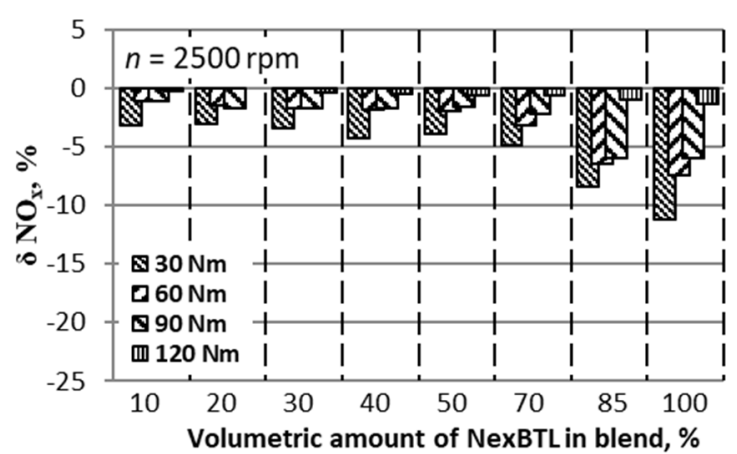

(b)

Figure 11. Relative deviation of $\mathrm{NO}_{\mathbf{x}}:(\mathbf{a}) n=2000 \mathrm{rpm}$; (b) $n=2500 \mathrm{rpm}$.

In general, the concentration of the incomplete combustion product $\mathrm{HC}$ in the exhaust gas was reduced. A reduction of up to $12 \%$ was achieved at speed regime of $n=2000 \mathrm{rpm}$ and was up to $15-25 \%$ at $n=2500 \mathrm{rpm}$ using the NexBTL85 blend and pure NexBTL (Figure 12a,b). In addition, NexBTL30 and NexBTL50 showed higher concentrations of HC than for the pure diesel fuel, with up to $8 \%$ at speed regime $n=2000 \mathrm{rpm}$ and up to $12 \%$ at $\mathrm{n}=2500 \mathrm{rpm}$. This can be explained by the better evaporation of the HVO fuel component and the formation of lighter hydrocarbon fractions in the fuel chamber areas. However, it is difficult to declare an obvious advantage or disadvantage in the cases of NexBTL30, NexBTL40 and NexBTL50 because, in these cases of diesel and NexBTL blends, the Pro Diesel fuel was purchased from the NESTE Company's gas station (Section 2.3). In these fuel mixtures, additional anticorrosive blending components and mixture stabilizers are used $[34,55]$. The reduction of the HC concentration in the exhaust gas could be explained by a more complete combustion, which occurred due to the higher $\mathrm{H} / \mathrm{C}$ ratio and the simpler $\mathrm{HVO}$ molecular chain [35,42], which easily reacts with oxygen in the cylinder. 


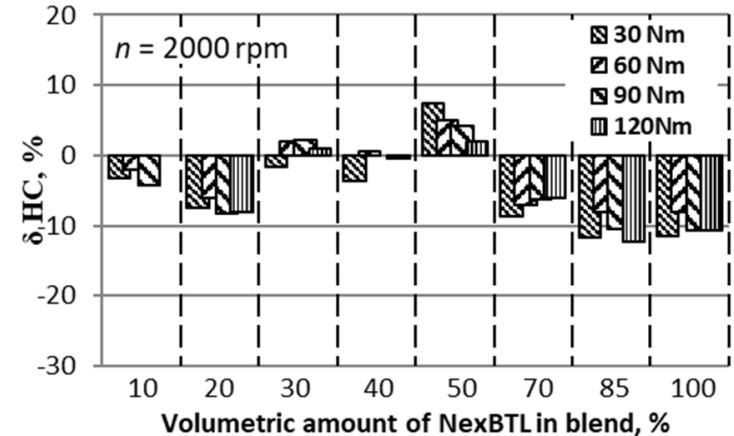

(a)

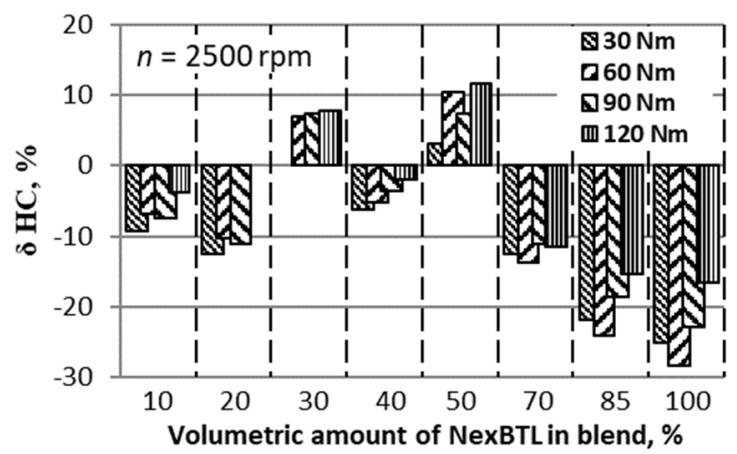

(b)

Figure 12. Relative deviation of HC: (a) $n=2000 \mathrm{rpm}$; (b) $n=2500 \mathrm{rpm}$.

The most significant change and the smoothest trends were achieved when analyzing the opacity of the exhaust gas or the smokiness (SM). The relative deviation of SM (Figure 13a,b) show a clear advantage of NexBTL compared with pure diesel. The higher level of SM reduction was achieved by the increased percentage of NexBTL. The engine speed regime $n=2000 \mathrm{rpm}$ showed a reduction from $2 \%$ to approximately $35 \%$ and regime $n=2500 \mathrm{rpm}$ from $5 \%$ to approximately $40 \%$. Usually, at the same speed regime, high load points are characterized by a higher level of smokiness [42,51]; often more fuel was injected and provided for the oxidation reactions during the same time, and therefore, a more incomplete combustion occurs. NexBTL showed the highest advantage in the highest load points. The decrease in SM was influenced by the composition of $\mathrm{HVO}$, which contains almost $100 \%$ alkanes (paraffinic hydrocarbons) [58] that do not contain aromatic hydrocarbons and other mineral impurities that increase soot formation during combustion [40,55].

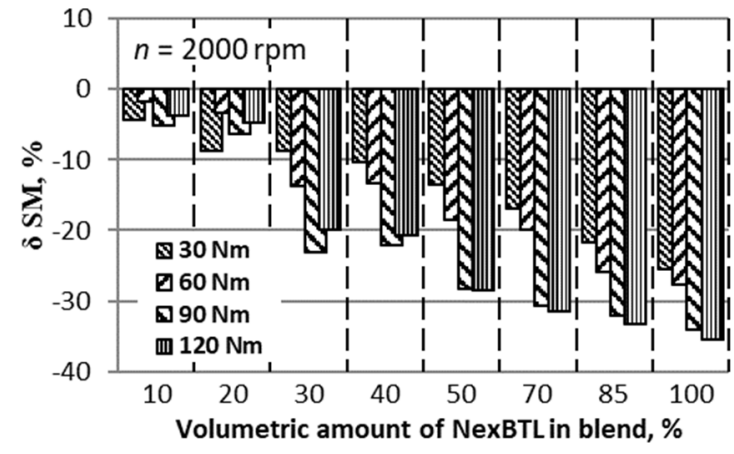

(a)

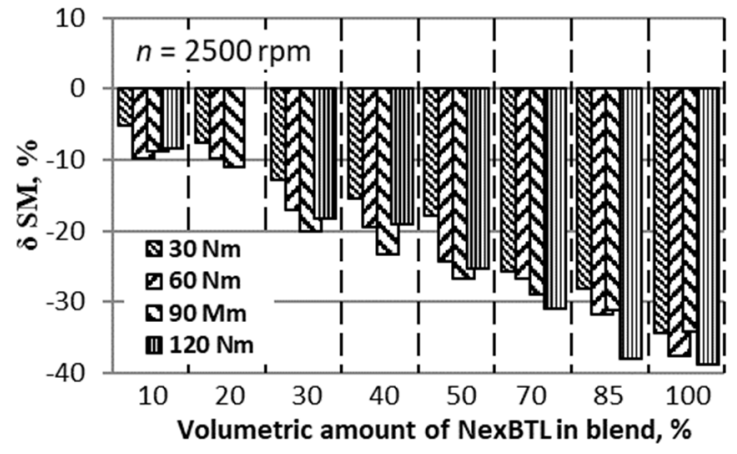

(b)

Figure 13. Relative deviation of the smokiness (SM): (a) $n=2000 \mathrm{rpm}$; (b) $n=2500 \mathrm{rpm}$.

\section{Conclusions}

This paper contains broad results of the influence of hydrotreated vegetable oil blending components on engine performance parameters. Here, parameters such as BSFC, BTE, air polluting compounds and fuel properties were assessed. These results are valuable for practical use and for scientific purposes because a wide range of fuel mixing ratios were used. The research covers seven examples of different ratio blends between pure diesel fuel and pure hydrotreated vegetable oil, which called NexBTL. The analysis of the tested fuel properties (dynamic and kinematic viscosity, density, water content, pour point, cold filter plugging point and cetane number, gross/lower heating value and oxidative stability) showed increased diffusion combustion and a strong dependency on amount of NexBTL in the fuel blend.

The analysis of combustion rates did not show significant changes. The difference between $R O H R$ values only increased by $1.5 \mathrm{~J} /{ }^{\circ} \mathrm{CA}$, and the higher difference resulted by a delayed or advanced 
combustion process. It has been reported that increasing the concentration of NexBTL in the diesel combustion delay period shortens this period, but the premixed combustion phase is advanced due to its higher $\mathrm{CN}$.

An analysis of brake specific fuel consumption, which is the main economic factor, showed controversial results due to an approximately $7.7 \%$ lower density and an approximately $2.0 \%$ higher LHV of NexBTL. Compared with pure diesel fuel, the BSFC_m (according to mass) decreased (relatively) by $3.5 \%$ when NexBTL reached close to the maximum (NexBTL100) percentages in the fuel blends. However, the results of volumetric $B S F C_{-} V$ showed an increase (relative) of up to $4-6 \%$ of the fuel consumption for both studied speed regimes $(n=2000 \mathrm{rpm}$ and $n=2500 \mathrm{rpm}$ ), at almost all the load points $\left(16.6-66.6 \% M_{B}\right)$. The analysis showed that the use of NexBTL and its blends in a direct injection diesel engine with an electronically controlled distribution type fuel pump has better fuel mass consumption rates, but the volumetric consumption is higher than within pure diesel fuel due to the lower density. This fact is important at the vehicle user level because the retail fuel market is based on fuel volume sales.

Despite the results of $B S F C$, the energy conversion of NexBTL seemed more effective than pure diesel fuel. The change in the BTE is close to constant or only slightly depends on the load or speed regime. The range of the BTE increases (according scale) by approximately $0.5-1.4 \%$ and covers mainly all test points.

$\mathrm{CO}, \mathrm{CO}_{2}, \mathrm{NO}_{\mathrm{x}}, \mathrm{HC}$ and $\mathrm{SM}$ were analyzed during this research. The change in $\mathrm{CO}$ was negligible with an increasing amount of NexBTL in the fuel blend. The reduction of $\mathrm{CO}_{2}$ was up to $0.3-0.35 \%$, and the maximum reduction was achieved when the percentage of NexBTL increased up to $85-100 \%$. The $\mathrm{NO}_{\mathrm{x}}$ rates were (relatively) reduced by approximately $3-20 \%$ at low engine loads. However, the results of the least load regimes showed the (relative) $\mathrm{NO}_{x}$ reduction by approximately $0.5-7.5 \%$; maximum reduction values were achieved by a high concentration of NexBTL. The HC concentration was (relatively) reduced by $12 \%$ at speed regime $n=2000 \mathrm{rpm}$ and up to $15-25 \%$ at $n=2500 \mathrm{rpm}$ using the NexBTL85 blend and pure NexBTL. The most obvious advantage was observed while analyzing the change in the smokiness. The higher SM reduction was achieved by an increased percentage of NexBTL, which reduced the SM from $2 \%$ to approximately $35 \%(n=2000 \mathrm{rpm})$ and from $5 \%$ to approximately $40 \%(n=2500 \mathrm{rpm})$.

Hydrotreated vegetable oil, the NexBTL blending component for diesel fuel, significantly reduces the major engine pollution (NOx and $\mathrm{SM}$ ) emissions due to lower $\mathrm{C} / \mathrm{H}$ ratios, simpler molecular structures, higher CN and other physical-chemical properties. NexBTL accounts for up to $50 \%$ of the fuel sold at gas stations. These properties of these removable fuels are advantageous, because, with the fatty acid methyl ester (FAME) blending components, engine smoke decreases but NOx emissions increase [59]. The amount of FAME in the fuel is limited [17]. The NexBTL blending component for diesel fuel increases the fuel consumption, but the engine's BTE tends to increase.

Author Contributions: Conceptualization, A.R. and J.Ž.; methodology, A.R., S.S. and J.Ž.; software, P.R. and S.S.; formal analysis, Á.B. and S.S.; validation, J.Ž. and P.R.; writing-original draft preparation, J.Ž., A.R. and Á.B.; writing—review and editing, Á.B. and J.M.; supervision, A.R., and J.M.; project administration, J.M.

Funding: The Higher Education Excellence Program of the Ministry of Human Capacities in the biotechnology research area of the Budapest University of Technology and Economics (BME FIKP-BIO).

Acknowledgments: Authors are grateful to JSC “NESTE Lietuva" for providing the possibility to test the advanced hydrotreated vegetable oil called "NexBTL". A part of the results of the research described in this article were obtained using the engine simulation tool AVL BOOST, acquired by signing a Cooperation Agreement between AVL Advanced Simulation Technologies and the faculty of the Transport Engineering of Vilnius Gediminas Technical University. The research reported in this paper was supported by the Higher Education Excellence Program of the Ministry of Human Capacities in the biotechnology research area of the Budapest University of Technology and Economics (BME FIKP-BIO).

Conflicts of Interest: The authors declare no conflict of interest. 


\section{Appendix A}

Table A1. Main parameters of tested fuels.

\begin{tabular}{|c|c|c|c|c|c|c|c|c|c|}
\hline \multirow{2}{*}{ Properties } & \multicolumn{9}{|c|}{ Fuel } \\
\hline & $\begin{array}{l}\text { Nex } \\
\text { BTL0 }\end{array}$ & $\begin{array}{c}\text { Nex } \\
\text { BTL10 }\end{array}$ & $\begin{array}{c}\text { Nex } \\
\text { BTL20 }\end{array}$ & $\begin{array}{l}\text { Nex** } \\
\text { BTL30 }\end{array}$ & $\begin{array}{l}\text { Nex*** } \\
\text { BTL40 }\end{array}$ & $\begin{array}{l}\text { Nex } * * * * \\
\text { BTL50 }\end{array}$ & $\begin{array}{c}\text { Nex } \\
\text { BTL70 }\end{array}$ & $\begin{array}{c}\text { Nex } \\
\text { BTL85 }\end{array}$ & $\begin{array}{c}\text { Nex } \\
\text { BTL100 }\end{array}$ \\
\hline Dynamic viscosity, $\mathrm{mPa} \times \mathrm{s}$ & 3.271 & 3.125 & 2.993 & 2.550 & 2.451 & 2.365 & 2.478 & 2.360 & 2.262 \\
\hline Kinematic viscosity, $\mathrm{mm}^{2} / \mathrm{s}$ & 3.947 & 3.802 & 3.672 & 3.149 & 3.034 & 3.000 & 3.163 & 3.0498 & 2.959 \\
\hline Density at $40^{\circ} \mathrm{C}, \mathrm{g} / \mathrm{ml}$ & $0.8469 *$ & 0.822 & 0.815 & 0.810 & 0.808 & 0.793 & 0.783 & 0.774 & $0.7798 *$ \\
\hline Water content acc. $\mathrm{CF}, \%$ & 0.0033 & 0.0031 & 0.0027 & 0.0025 & 0.0023 & 0.0021 & 0.002 & 0.002 & 0.002 \\
\hline Oxidative stability, $\min$ & 70.31 & 83.11 & 84.6 & 75.21 & 72.11 & 73.78 & 105 & 116 & 126.43 \\
\hline $\mathrm{CFPP},{ }^{\circ} \mathrm{C}$ & -10 & -12 & -16 & -27 & -28 & -33 & -34 & -34 & -40 \\
\hline Cetane number & 50.9 & 54.5 & 56.4 & 58.1 & 59.6 & 59.9 & 68.5 & 71.7 & 74.5 \\
\hline Pour point, ${ }^{\circ} \mathrm{C}$ & -39 & -39 & -40 & -40 & -42 & -45 & -40 & -46 & -58 \\
\hline Gross heating value, $\mathrm{MJ} / \mathrm{kg}$ & 45.876 & 46.025 & 46.155 & 46.272 & 46.289 & 46.411 & 46.761 & 46.923 & 47.218 \\
\hline Lower heating value $L H V, \mathrm{MJ} / \mathrm{kg}$ & 42.570 & 42.672 & 42.757 & 42.827 & 42.916 & 42.873 & 43.131 & 43.223 & 43.449 \\
\hline
\end{tabular}

\section{References}

1. Benito, A.; Alonso, G. Energy Efficiency and the Environment. In Energy Efficiency in Air Transportation; Elsevier: Amsterdam, The Netherlands, 2018; pp. 153-199. ISBN 9780128125816.

2. Dimitriou, I.; Goldingay, H.; Bridgwater, A.V. Techno-Economic and Uncertainty Analysis of Biomass to Liquid (BTL) Systems for Transport Fuel Production. Renew. Sustain. Energy Rev. 2018, 88, 160-175. [CrossRef]

3. Goldemberg, J.; Souza, G.M.; Maciel-Filho, R.; Cantarella, H. Scaling up Biofuels? A Critical Look at Expectations Performance and Governance. Energy Policy 2018, 118, 655-657. [CrossRef]

4. Haasz, T.; Gómez Vilchez, J.J.; Kunze, R.; Deane, P.; Fraboulet, D.; Fahl, U.; Mulholland, E. Perspectives on Decarbonizing the Transport Sector in the EU-28. Energy Strategy Rev. 2018, 20, 124-132. [CrossRef]

5. Arthanarisamy, M.; Alagumalai, A.; Natarajan, N. Biodiesel as an Alternative Transportation Fuel in Diesel Engines an In-Depth Study on Biodiesel Performance; LAMBERT Academic Publishing: Riga, Latvia, 2016.

6. Brynolf, S.; Taljegard, M.; Grahn, M.; Hansson, J. Electrofuels for the Transport Sector: A Review of Production Costs. Renew. Sustain. Energy Rev. 2018, 81, 1887-1905. [CrossRef]

7. No, S.-Y. Application of Hydrotreated Vegetable Oil from Triglyceride Based Biomass to CI EnginesA Review. Fuel 2014, 115, 88-96. [CrossRef]

8. Zöldy, M. Automotive Industry Solutions in Response to European Legislative Emission Regulation Challenge. Moksl.-Liet. Ateitis 2009, 1, 33-40. [CrossRef]

9. Zöldy, M.; Török, Á. Road Transport Liquid Fuel Today and Tomorrow: Literature Overview. Period. Polytech. Transp. Eng. 2015, 43, 172-176. [CrossRef]

10. Çelebi, Y.; Aydın, H. An Overview on the Light Alcohol Fuels in Diesel Engines. Fuel 2019, 236, 890-911. [CrossRef]

11. Lorenzi, G.; Baptista, P. Promotion of Renewable Energy Sources in the Portuguese Transport Sector: A Scenario Analysis. J. Clean. Prod. 2018, 186, 918-932. [CrossRef]

12. Knothe, G.; Razon, L.F. Biodiesel Fuels. Prog. Energy Combust. Sci. 2017, 58, 36-59. [CrossRef]

13. Singh, D.; Subramanian, K.A.; Garg, M. Comprehensive Review of Combustion, Performance and Emissions Characteristics of a Compression Ignition Engine Fueled with Hydroprocessed Renewable Diesel. Renew. Sustain. Energy Rev. 2018, 81, 2947-2954. [CrossRef]

14. AOCS Press. The Biodiesel Handbook, 2nd ed.; Knothe, G., Ed.; AOCS Press: Urbana, IL, USA, 2010.

15. Urzędowska, W.; Stępień, Z. Prediction of Threats Caused by High FAME Diesel Fuel Blend Stability for Engine Injector Operation. Fuel Process. Technol. 2016, 142, 403-410. [CrossRef]

16. Zhong, W.; Tamilselvan, P.; Wang, Q.; He, Z.; Feng, H.; Yu, X. Experimental Study of Spray Characteristics of Diesel/Hydrogenated Catalytic Biodiesel Blended Fuels under Inert and Reacting Conditions. Energy 2018, 153, 349-358. [CrossRef] 
17. Hossain, F.M.; Rainey, T.J.; Ristovski, Z.; Brown, R.J. Performance and Exhaust Emissions of Diesel Engines Using Microalgae FAME and the Prospects for Microalgae HTL Biocrude. Renew. Sustain. Energy Rev. 2018, 82, 4269-4278. [CrossRef]

18. Mulholland, E.; Teter, J.; Cazzola, P.; McDonald, Z.; Gallachóir, B.P.Ó. The Long Haul towards Decarbonising Road Freight-A Global Assessment to 2050. Appl. Energy 2018, 216, 678-693. [CrossRef]

19. Palanisamy, S.; Gevert, B.S. Hydroprocessing of Fatty Acid Methyl Ester Containing Resin Acids Blended with Gas Oil. Fuel Process. Technol. 2014, 126, 435-440. [CrossRef]

20. Suarez-Bertoa, R.; Kousoulidou, M.; Clairotte, M.; Giechaskiel, B.; Nuottimäki, J.; Sarjovaara, T.; Lonza, L. Impact of HVO Blends on Modern Diesel Passenger Cars Emissions during Real World Operation. Fuel 2019, 235, 1427-1435. [CrossRef]

21. Wang, W.-C. Techno-Economic Analysis of a Bio-Refinery Process for Producing Hydro-Processed Renewable Jet Fuel from Jatropha. Renew. Energy 2016, 95, 63-73. [CrossRef]

22. Aatola, H.; Larmi, M.; Sarjovaara, T.; Mikkonen, S. Hydrotreated Vegetable Oil (HVO) as a Renewable Diesel Fuel: Trade-off between NOx, Particulate Emission, and Fuel Consumption of a Heavy Duty Engine. SAE Int. J. Engines 2008, 1, 1251-1262. [CrossRef]

23. Ashok, B.; Nanthagopal, K.; Anand, V.; Aravind, K.M.; Jeevanantham, A.K.; Balusamy, S. Effects of N-Octanol as a Fuel Blend with Biodiesel on Diesel Engine Characteristics. Fuel 2019, 235, 363-373. [CrossRef]

24. Mancaruso, E.; Sequino, L.; Vaglieco, B.M. First and Second Generation Biodiesels Spray Characterization in a Diesel Engine. Fuel 2011, 90, 2870-2883. [CrossRef]

25. Rimkus, A.; Žaglinskis, J.; Rapalis, P.; Skačkauskas, P. Research on the Combustion, Energy and Emission Parameters of Diesel Fuel and a Biomass-to-Liquid (BTL) Fuel Blend in a Compression-Ignition Engine. Energy Convers. Manag. 2015, 106, 1109-1117. [CrossRef]

26. Žaglinskis, J.; Lukács, K.; Bereczky, Á. Comparison of Properties of a Compression Ignition Engine Operating on Diesel-Biodiesel Blend with Methanol Additive. Fuel 2016, 170, 245-253. [CrossRef]

27. Choi, Y.H.; Jang, Y.J.; Park, H.; Kim, W.Y.; Lee, Y.H.; Choi, S.H.; Lee, J.S. Carbon Dioxide Fischer-Tropsch Synthesis: A New Path to Carbon-Neutral Fuels. Appl. Catal. B Environ. 2017, 202, 605-610. [CrossRef]

28. VCH. Handbook of Heterogeneous Catalysis; Ertl, G., Ed.; VCH: Weinheim, Germany, 1997.

29. Napolitano, P.; Guido, C.; Beatrice, C.; Pellegrini, L. Impact of Hydrocracked Diesel Fuel and Hydrotreated Vegetable Oil Blends on the Fuel Consumption of Automotive Diesel Engines. Fuel 2018, 222, 718-732. [CrossRef]

30. Ibarra-Gonzalez, P.; Rong, B.-G. A Review of the Current State of Biofuels Production from Lignocellulosic Biomass Using Thermochemical Conversion Routes. Chin. J. Chem. Eng. 2018. [CrossRef]

31. Naylor, R.L.; Higgins, M.M. The Rise in Global Biodiesel Production: Implications for Food Security. Glob. Food Secur. 2018, 16, 75-84. [CrossRef]

32. Demirbaş, A. Biodiesel: A Realistic Fuel Alternative for Diesel Engines; Springer: London, UK, 2008.

33. Zöldy, M. Ethanol-Biodiesel-Diesel Blends as A Diesel Extender Option On Compression Ignition Engines. Transport 2011, 26, 303-309. [CrossRef]

34. Neste Renewable Diesel Handbook—Reports. Available online: https:/docgo.net/viewdoc.html?utm source=neste-renewable-diesel-handbook (accessed on 20 February 2019).

35. Li, Y.; Xu, H.; Cracknell, R.; Head, R.; Shuai, S. An experimental investigation into combustion characteristics of HVO compared with TME and ULSD at varied blend ratios. Fuely 2019, 255, 115757. [CrossRef]

36. Lin, K.-W.; Wu, H.-W. Thermodynamic Analysis and Experimental Study of Partial Oxidation Reforming of Biodiesel and Hydrotreated Vegetable Oil for Hydrogen-Rich Syngas Production. Fuel 2019, 236, 1146-1155. [CrossRef]

37. Kumar, A.N.; Brahma Raju, K.; Srinivas Kishore, P.; Narayana, K. Some Experimental Studies on Effect of Exhaust-Gas Recirculation on Performance and Emission Characteristics of a Compression-Ignition Engine Fuelled with Diesel and Lemon-Peel Oil Blends. Mater. Today Proc. 2018, 5, 6138-6148. [CrossRef]

38. Preuß, J.; Munch, K.; Denbratt, I. Performance and Emissions of Long-Chain Alcohols as Drop-in Fuels for Heavy Duty Compression Ignition Engines. Fuel 2018, 216, 890-897. [CrossRef]

39. Singh, D.; Subramanian, K.A.; Bal, R.; Singh, S.P.; Badola, R. Combustion and Emission Characteristics of a Light Duty Diesel Engine Fueled with Hydro-Processed Renewable Diesel. Energy 2018, 154, 498-507. [CrossRef] 
40. Han, M. The Effects of Synthetically Designed Diesel Fuel Properties-Cetane Number, Aromatic Content, Distillation Temperature, on Low-Temperature Diesel Combustion. Fuel 2013, 109, 512-519. [CrossRef]

41. Millo, F.; Debnath, B.K.; Vlachos, T.; Ciaravino, C.; Postrioti, L.; Buitoni, G. Effects of Different Biofuels Blends on Performance and Emissions of an Automotive Diesel Engine. Fuel 2015, 159, 614-627. [CrossRef]

42. Niemi, S.; Vauhkonen, V.; Mannonen, S.; Ovaska, T.; Nilsson, O.; Sirviö, K.; Heikkilä, S.; Kiijärvi, J. Effects of Wood-Based Renewable Diesel Fuel Blends on the Performance and Emissions of a Non-Road Diesel Engine. Fuel 2016, 186, 1-10. [CrossRef]

43. Masera, K.; Hossain, A.K. Biofuels and Thermal Barrier: A Review on Compression Ignition Engine Performance, Combustion and Exhaust Gas Emission. J. Energy Inst. 2018. [CrossRef]

44. Gill, S.S.; Tsolakis, A.; Dearn, K.D.; Rodríguez-Fernández, J. Combustion Characteristics and Emissions of Fischer-Tropsch Diesel Fuels in IC Engines. Prog. Energy Combust. Sci. 2011, 37, 503-523. [CrossRef]

45. Abián, M.; Martín, C.; Nogueras, P.; Sánchez-Valdepeñas, J.; Rodríguez-Fernández, J.; Lapuerta, M.; Alzueta, M.U. Interaction of Diesel Engine Soot with NO2 and O2 at Diesel Exhaust Conditions. Effect of Fuel and Engine Operation Mode. Fuel 2018, 212, 455-461. [CrossRef]

46. Bohl, T.; Smallbone, A.; Tian, G.; Roskilly, A.P. Particulate Number and NO x Trade-off Comparisons between HVO and Mineral Diesel in HD Applications. Fuel 2018, 215, 90-101. [CrossRef]

47. Yamada, H.; Misawa, K.; Suzuki, D.; Tanaka, K.; Matsumoto, J.; Fujii, M.; Tanaka, K. Detailed Analysis of Diesel Vehicle Exhaust Emissions: Nitrogen Oxides, Hydrocarbons and Particulate Size Distributions. Proc. Combust. Inst. 2011, 33, 2895-2902. [CrossRef]

48. D'Alessandro, B.; Bidini, G.; Zampilli, M.; Laranci, P.; Bartocci, P.; Fantozzi, F. Straight and Waste Vegetable Oil in Engines: Review and Experimental Measurement of Emissions, Fuel Consumption and Injector Fouling on a Turbocharged Commercial Engine. Fuel 2016, 182, 198-209. [CrossRef]

49. Wakode, V.R.; Kanase-Patil, A.B. Regression Analysis and Optimization of Diesel Engine Performance for Change in Fuel Injection Pressure and Compression Ratio. Appl. Therm. Eng. 2017, 113, 322-333. [CrossRef]

50. Zoldy, M.; Hollo, A.; Thernesz, A. Butanol as a Diesel Extender Option for Internal Combustion Engines; SAE International: Warrendale, PA, USA, 2010.

51. Kim, D.; Kim, S.; Oh, S.; No, S.-Y. Engine Performance and Emission Characteristics of Hydrotreated Vegetable Oil in Light Duty Diesel Engines. Fuel 2014, 125, 36-43. [CrossRef]

52. Singer, A.; Schröder, O.; Pabst, C.; Munack, A.; Bünger, J.; Ruck, W.; Krahl, J. Aging Studies of Biodiesel and HVO and Their Testing as Neat Fuel and Blends for Exhaust Emissions in Heavy-Duty Engines and Passenger Cars. Fuel 2015, 153, 595-603. [CrossRef]

53. Yilmaz, N.; Atmanli, A. Experimental Assessment of a Diesel Engine Fueled with Diesel-Biodiesel-1-Pentanol Blends. Fuel 2017, 191, 190-197. [CrossRef]

54. Yilmaz, N.; Atmanli, A.; Vigil, F.M. Quaternary Blends of Diesel, Biodiesel, Higher Alcohols and Vegetable Oil in a Compression Ignition Engine. Fuel 2018, 212, 462-469. [CrossRef]

55. Zaharin, M.S.M.; Abdullah, N.R.; Najafi, G.; Sharudin, H.; Yusaf, T. Effects of Physicochemical Properties of Biodiesel Fuel Blends with Alcohol on Diesel Engine Performance and Exhaust Emissions: A Review. Renew. Sustain. Energy Rev. 2017, 79, 475-493. [CrossRef]

56. Fangsuwannarak, K.; Wanriko, P.; Fangsuwannarak, T. Effect of Bio-Polymer Additive on the Fuel Properties of Palm Biodiesel and on Engine Performance Analysis and Exhaust Emission. Energy Procedia 2016, 100, 227-236. [CrossRef]

57. Kuo, K.K. Principles of Combustion, 2nd ed.; Wiley: Hoboken, NJ, USA, 2005.

58. Vrtiška, D.; Šimáček, P. Prediction of HVO Content in HVO/Diesel Blends Using FTIR and Chemometric Methods. Fuel 2016, 174, 225-234. [CrossRef]

59. Hoekman, S.K.; Robbins, C. Review of the Effects of Biodiesel on NOx Emissions. Fuel Process. Technol. 2012, 96, 237-249. [CrossRef]

(C) 2019 by the authors. Licensee MDPI, Basel, Switzerland. This article is an open access article distributed under the terms and conditions of the Creative Commons Attribution (CC BY) license (http://creativecommons.org/licenses/by/4.0/). 